\title{
雪室貯蔵が小麦粉の品質と製パン性に与える影響
}

\author{
神山 伸 $^{\dagger}$, 櫛原詩野, 本間千裕，萩原 真，曾根英行 \\ 新潟県立大学 人間生活学部 健康栄養学科
}

\section{Effectiveness of Snow Utilization for Preservation of Wheat Flour}

\author{
Shin KAMIYAMA ${ }^{\dagger}$, Shino KUSHIHARA, Chihiro HOMMA, \\ Makoto HAGIWARA, Hideyuki SONE

\begin{abstract}
Department of Health and Nutrition, Faculty of Human Life Studies, University of Niigata Prefecture 471 Ebigase, Higashi-ku, Niigata city 950-8680, Japan
\end{abstract}

\begin{abstract}
Yukimuro means "snow room" in Japanese and has been used to preserve vegetables and other foods under low temperature by using natural energy. Here we investigated the effectiveness of snow utilization for the storage of wheat flour. Strong and whole grain flours were packed into paper bags and stored for three months under three different conditions: at room temperature, in a cold refrigerator, and in a moist cold snow room (i.e., yukimuro) and provided for analyses. As compared with the samples stored at room temperature, both cold storage in refrigerator and moist cold storage in snow room reduced lipid peroxidation and generation of free fatty acid. The wheat flours stored in yukimuro showed better bread-making properties than those stored at room temperature or in refrigerator. The brown bread made from the flours stored in yukimuro showed better sensory evaluation scores. These findings indicate that moist cold storage in snow room (yukimuro) suppresses lipid oxidation and improves bread-making properties of wheat flours.
\end{abstract}

Keywords: Snow room, yukimuro, wheat four, bread, quality preservation

\section{1. 緒古}

新潟県の山間部のような豪雪地域では，雪を利用し た食品の保存が古くから行われてきた。雪利用による 農作物の保存では，農作物を収穫せずに雪の下に放置 する「雪下貯蔵」や，コンテナなどに入れた食品を野 外の雪の中で貯蔵する「雪中貯蔵」，雪室に貯蔵した雪 を冷房源として夏の間の食品貯蔵などに利用する「雪 室貯蔵」などがあり，いずれも低温・高湿度の環境を 保てることから，農作物の乾燥を防ぎ，その品質を保 持する上でも有用である。冬期の多量の降雪を冷却資 源として利用する雪室貯蔵は，近代まで北陸の積雪地 域では一般的なものであったが，電気利用冷蔵庫の普 及により次第に利用されなくなり，その多くが姿を消 して行った．近年になって，人参 [1] やじゃがいも，大 根，キャベッ，白菜 [2] などの農産物では雪中保存によ り呈味が向上することが示され，高付加価值商品とし ての雪室利用が注目されるようになった。さらにまた，

(受付 2016 年 9 月 30 日，受理 2016 年 11 月 26 日)

厂950-8680 新潟市東区海老ヶ瀬 471

†FAX: 025-368-8269, E-mail: kammy@unii.ac.jp
雪を利用した貯蔵は冷蔵装置を必要とせずに安定した 低温を維持できることから，二酸化炭素を排出しない 環境に優しい貯蔵方法としても注目されている.

主要農産物である米扎よび麦に関しては，低温貯蔵 の有効性が品質保持の上で認められているものの, 雪 室の高湿度の条件 (90\%以上) が貯蔵におけるデメリッ 卜となる可能性があり，これまで雪室利用は限定的で あった。 日本では大部分の米は玄米の状態で常温貯蔵 されているが， $15^{\circ} \mathrm{C}$ 以下であればカビや害虫の繁殖も 少なく，また米の呼吸も抑えられることから，近年で は温度を $15^{\circ} \mathrm{C}$ 以下，湿度を $70 \sim 80 \%$ に調温・調湿した 低温貯蔵倉庫による貯蔵が一般化してきており，雪利 用冷蔵を玄米の貯蔵に利用しようとする試みも増えて きている。一方，小麦に扔いても，力ビや害虫の繁殖 を抑制し，胚芽中の酵素活性による変性を少なくする ため，なるべく低温での保存が推奨されているが，小 麦は良好な貯蔵条件であれば長期保存が可能であり, また新米の状態がもっとも好まれる米に対し，収穫直 後の肧芽の酵素活性が高い状態よりもある程度熟成 （エージング）が進んだ方が，品質が安定化し加工特性 が向上するため好ましいとされている．また，玄米の 
貯蔵においては，含水率が $14 \%$ 以下に低下した過乾燥 米は表面と内部との水分差が増加することにより亀裂 が生じた胴割米となり, 精米時の砕米の発生や吸水時 のひび割れなどにより食味が低下するが，主に粉食と して利用される小麦は小麦粒の水分が $12 \%$ 以下となる 乾燥状態の方が好ましいため, 高湿度である雪室を用 いた検討はなされていなかった。

これまでの研究で筆者らは，コーヒーのような加工 食品においても雪利用貯蔵が有効であることについて 報告してきた [3]. また，山間地で米の代替作物として 栽培されるソバに関して, ソバの香気と品質保持にお ける雪室貯蔵の有效性を報告した [4]，本研究では，雪 室を利用した小麦の高付加価値食品の生産を可能とす るため, 品質が劣化しやすい製粉加工物を対象として 雪室貯蔵の有効性を評価した。すすおわち, 小麦粉を常温, 冷蔵室, 雪室の条件で貯蔵し，それぞれの品質を比較 することにより，低温・高湿度である雪室貯蔵が冷蔵 室貯蔵と比べて同等あるいはそれ以上の効果を持つか ぞうかについて検討した。また，これらの貯蔵小麦粉 の製パン性とその食味を把握することにより，雪室貯 蔵による加工特性向上の可能性を検討した。これらの 検討により, 雪室貯蔵による品質保持効果と, 高付加 価值食品としての小麦粉の生産の可能性を試みた。

\section{2. 実験}

\section{1 試料の貯蔵条件}

丸榮製粉株式会社（新潟市江南区）より購入した強 力粉（ファースト）と全粒粉（雪ちから）を試料とし て用いた，製粉直後のそれぞれの試料を通常の紙製貯 蔵用袋に入れ，（1）常温貯蔵 $\left(22 \sim 28^{\circ} \mathrm{C}\right)$ (2) 冷蔵室 貯蔵 $\left(5 \sim 10^{\circ} \mathrm{C}\right) \quad(3)$ 雪室貯蔵 $\left(1 \sim 5^{\circ} \mathrm{C}\right)$ の 3 条件を設 定して保存することにより比較検討した。いずれの貯 蔵でも, 紙袋に水滴が付着することを防ぐため, ポリ エチレン袋（業務用ポリ袋 LD35-70，福助工業製，厚 さ $0.035 \mathrm{~mm}$ 低密度ポリエチレン製, 容量 $70 \mathrm{~L}$ ) の中 に袋の口を密封しない状態で入れて行い，気体が自由 に通過できるプラスチック製コンテナ内に貯蔵した。 雪室貯蔵は新潟県上越市安塚区の雪室貯蔵庫を利用し て行い, 冷蔵室貯蔵は新潟県立大学の低温室 $\left(6^{\circ} \mathrm{C}\right.$ 設定 $)$ で行った。常温貯蔵は新潟県立大学の保管室（空調設 備なし）の暗所に保存した。貯蔵期間はいずれも平成 26 年 7 月〜 9 月の 3 か月とし, Thermo Recorder 打ん どとり TR-72wf-H（T\&D Corporation 製）を用いて, 貯蔵中に打ける温度と湿度の変化を測定した。貯蔵終 了後は，ただちに $-30^{\circ} \mathrm{C}$ の冷凍庫に入れ，分析時まで冷 凍保存した。

\section{2 水分の測定}

常圧加熱乾燥法により測定した。恒量を求めたアル ミ皿に試料 $1 \mathrm{~g}$ をとり精秤し $, 135^{\circ} \mathrm{C}, 2$ 時間の加熱 $\rightarrow$ デシケータ中での 30 分間の放冷 $\rightarrow$ 科量を恒量になるま で繰り返した。

\section{3 遊離グルコース量の測定}

試料中の遊離グルコース量はグルコース CII ーテス トワコー（和光純薬工業）を使用して測定した。試料 各 $0.1 \mathrm{~g}$ に蒸留水 $0.5 \mathrm{~mL}$ を加え擋找抽出後, 12,000 $\mathrm{rpm}$ で 5 分間遠心分離した。 上清 $20 \mu \mathrm{L}$ をとり, 発色 試薬 $200 \mu \mathrm{L}$ を加え $37^{\circ} \mathrm{C}$ で 5 分間放置し波長 $490 \mathrm{~nm}$ で 吸光度を測定した。付属のグルコース標準液 $(200 \mathrm{mg}$ / dL）を用いて検量線を作成し，試料 $100 \mathrm{~g}$ あたりの遊 離グルコース量を算定した。

\section{4 遊離脂肪酸量の測定}

脂肪酸度としての遊離脂肪酸量を大坪らによる改良 比色法 [5]により測定した。試料 $0.1 \mathrm{~g}$ にトルエン 0.5 $\mathrm{mL}$ を加え, 10 分ごとに強く擋找しつつ $30^{\circ} \mathrm{C}$ で 30 分間 抽出した. $10,000 \mathrm{rpm}$ で 5 分間遠心分離し，上清 200 $\mu \mathrm{L}$ を回収した.クロロホルム $800 \mu \mathrm{L}$ と銅試薬（1 M 卜 リエタノールアミン， $1 \mathrm{M}$ 酢酸， $6.45 \%$ 硝酸銅水溶液の 9:1:10 混合溶液) $500 \mu \mathrm{L}$ を添加し, 強く混合擋找した後, $10,000 \mathrm{rpm}$ で 5 分間遠心分離した。 上部の青色の水層 を除去したのち，無色のクロロホルム層から $600 \mu \mathrm{L}$ を 採取した。発色液（ $0.1 \%$ ジエチルジチオカルバミン酸 ナトリウムのイソブタノール溶液) $100 \mu \mathrm{L}$ を添加し, $440 \mathrm{~nm}$ における吸光度を測定した。検量線は $1 \mathrm{mM}$ リ ノール酸標準液を用いて作成した。

\section{5 過酸化脂質の測定}

試料中の過酸化脂質は，チオバルビツール酸（thiobarbituric acid, TBA) 法 [6] により定量した. 試料約 1 $\mathrm{g}$ を精秤し, エーテル $2 \mathrm{~mL}$ を加えて混和し, 30 分放置 した後，遠心分離（3000 rpm，5 分間）により上清を 回収した。この操作を 2 回繰り返し，回収した脂質を 窒素ガスの下で乾固させた。これに $8.1 \%$ SDS 溶液 200 $\mu \mathrm{L}$ ，酩酸緩衝液（pH 3.5） $1.5 \mathrm{~mL} ， 0.8 \%$ ジブチルヒド ロキシトルエン $50 \mu \mathrm{L}, 5 \mathrm{mM} \mathrm{FeCl}_{2} 250 \mu \mathrm{L}$ を加え溶 解し, $0.66 \%$ TBA 溶液 $0.4 \mathrm{~mL}$ を加え混和し, 沸騰水浴 中で 1 時間加熱した. 加熱後, 水道水で室温まで泠却し, ピリジン・ブタノール (1:15) $1 \mathrm{~mL}$ を加えて混和抽出後, 遠心分離した。回収した上清について，532 nmに打け る吸光度を測定した。試料を含まない対照液について 同様の操作を行い, ブランクとした. TBA反応産物量 (TBA reactive substance, TBARS) は 1,1',3,3' テトラエ トキシプロパンを用いた標準液により検量線を作成し, マロンジアルデヒド相当量として算出した。 


\section{6 製パン性の検討}

それぞれの条件で眝蔵した強力粉と全粒粉を $1: 1 て ゙$ 混合した小麦粉について，水添加練成物のグルテン形 成能を湿麥量・乾焚量測定により測定するとともに, 市販のホームベーカリー（Panasonic 製 SD-BMS106） を用いて食パンを作成した。作成条件としては，1斤あ たり強力粉（ファースト） $125 \mathrm{~g}$ ，全粒粉（雪ちから） $125 \mathrm{~g}$ ，無塩バター $10 \mathrm{~g}$ ，グラニュー糖 $17 \mathrm{~g}$ ，スキムミ ルク $6 \mathrm{~g}$, 塩 $5 \mathrm{~g}$, 冷水 $200 \mathrm{~mL}$, ドライイースト（日清 カメリヤスーパードライイースト) $2.8 \mathrm{~g}$ の配合で行い, ホームベーカリーの「全粒粉パン」設定で行った。作 成したパンについては，冷却した後高さを測定すると ともに，なたね法によりその体積を評価した。

\section{8 テクスチャーの評価}

上部 (上端から $2 \mathrm{~cm}$ 下の部分), 中央部分, 下部 (下 端 $2 \mathrm{~cm}$ 上の部分）を $2 \mathrm{~cm}$ の厚さに切り分けたパンの テクスチャー（硬さ，粘着力，凝集性，弾力性，咀嚼性） についてテクスチュロメーター（JSV-TEX-100，日本 計測システム製）を用いて評価した。直径 $20 \mathrm{~mm}$ の円 柱プランジャを用い，試験速度 $0.5 \mathrm{~mm} /$ 秒，圧縮移動 距離 $10 \mathrm{~mm}$ の条件で測定した。負荷を与えた際の最大 荷重を硬さ，圧縮後プランジャを引き上げた際の負の 荷重を粘着力， 1 ストロークと 2 ストロークの圧縮エネ ルギーの比を凝集性，最大ピークに至る変化量の 1 ス トロークと 2 ストロークの比を弾力性として表した. 咀嚼性は硬さ $\times$ 凝集性 $\times$ 弾力性で求めた。

\section{9 官能評価}

新潟県立大学の女子学生 48 人 $(20 \sim 22$ 歳の健康的な 女性）を対象とし，常温，冷蔵室，雪室の条件のもと 紙袋で貯蔵した強力粉と全粒粉を $1: 1$ で混合した小麦 粉で作成したそれぞれのパンについて，順位法打よび 5 点評価法により官能検査を行った。順位法では，「打い しい」と感じられる順に順位をつけた合計点について， Newell \& MacFarlane の検定により $5 \%$ の危険率で試料 間の有意差を判定した. 評価法では,「色」,「香り」,「もっ ちり感」,「しっとり感」,「味」,「総合評価」の 6 つの 項目のそれぞれについて，-2 から+2 までの 5 段階評 価を行い，それぞれの項目の平均值について一元配置 分散分析と試料間の多重比較を行った。

\subsection{0 統計処理}

データは平均值土標準偏差として表示した。統計処 理は R プログラム（v3.1.3）を用いて一元配置分散分析 と Bonferroni 法による多重比較により，5\%を有意水 準として行った。

\section{3. 結果及び考察}

\section{1 保存条件}

貯蔵用紙袋に入れた試料は，密封していないポリエ チレン製の袋を覆いとして用い，その中に入れた状態 でそれぞれの条件で保存したが，貯蔵後の外見として は，いずれもカビの発生などは認められなかった。貯 蔵期間における覆い内部の温度と湿度の変化を Fig. 1 に示す。それぞれの平均温度は，常温貯蔵 $24.7^{\circ} \mathrm{C} \quad(19.8$ $\left.\sim 28.7^{\circ} \mathrm{C}\right)$, 冷蔵室貯蔵 $6.7^{\circ} \mathrm{C} \quad\left(5.0 \sim 10.5^{\circ} \mathrm{C}\right)$, 雪室貯蔵 $2.7^{\circ} \mathrm{C} \quad\left(1.1 \sim 5.1{ }^{\circ} \mathrm{C}\right)$ であり，平均湿度は常温貯蔵 $69.5 \%$ （51.2～79.4％)，冷蔵室貯蔵 $42.1 \%$ (37.4〜 $56.5 \%$ ），雪室貯蔵 $58.6 \%$ （56.0～80.1％）であった. 通常，雪室は湿度 $90 \%$ 以上の状態にあるが，覆いの内 部では貯蔵開始直後（湿度 $80 \%$ ）を除き，常に56 $60 \%$ の一定の湿度を示した。一方，冷蔵室は調湿しな い条件で行ったが，覆い内部の湿度はほほ $40 \%$ 程度で あった，常温に打いては，覆い内部の温度と湿度は相 関しており，50〜80\%の間で変動した。
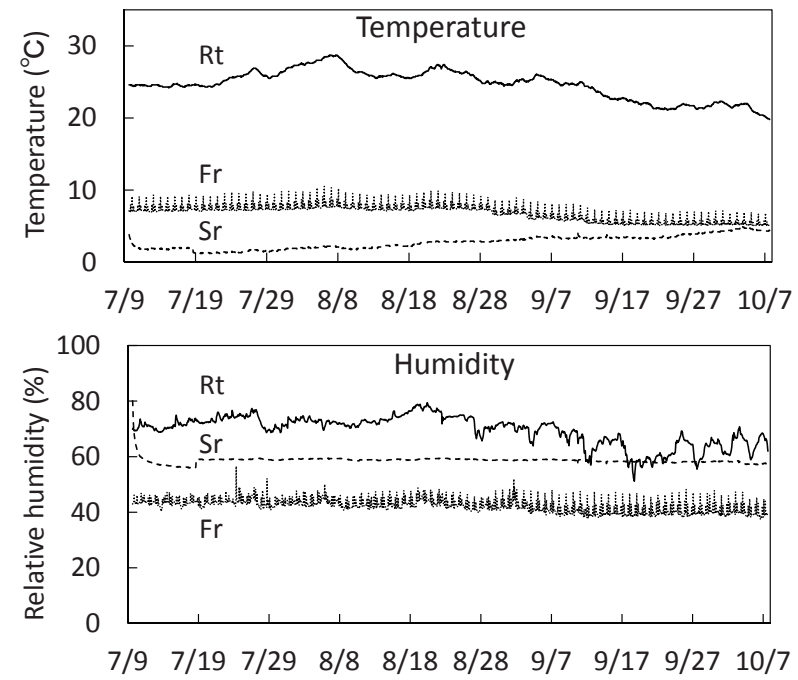

Fig. 1 Alteration of temperature and humidity during storage.

The temperature and humidity in the storage room were monitored using a thermo recorder. Upper panel, temperature; lower panel, humidity. Rt, ordinary room; Fr, refrigerating room; Sr, snow room.

\section{2 試料の水分量}

貯蔵終了後のそれぞれの試料の水分量を Table 1 に示 す. 初発状態の水分量は強力粉，全粒粉ともに $14 \%$ で あり，常温貯蔵においては，3ヶ月の貯蔵で大きな水分 量の変動はみられなかった。冷蔵室貯蔵では強力粉, 全粒粉ともに有意に水分が低下した。雪室貯蔵では, 全粒粉は常温貯蔵とほぼ同じ水分量であったが，強力 粉では常温貯蔵と冷蔵室貯蔵との中間の值を示した。 一般的に，穀物の水分量は温度と湿度環境と密接に関 係している．小麦粉の場合，吸湿と放湿が平衡化する 平衡水分量は，冷蔵室貯蔵の湿度であった $40 \%$ ではお 
Table 1 Water content (\%, wet basis) of wheat flours stored under different conditions.

\begin{tabular}{ccc}
\hline & Strong flour & Whole grain flour \\
\hline Rt & $14.3 \pm 0.1^{\mathrm{a}}$ & $14.0 \pm 0.2^{\mathrm{a}}$ \\
$\mathrm{Fr}$ & $12.9 \pm 0.1^{\mathrm{b}}$ & $12.5 \pm 0.2^{\mathrm{b}}$ \\
$\mathrm{Sr}$ & $13.6 \pm 0.2^{\mathrm{c}}$ & $14.3 \pm 0.5^{\mathrm{a}}$ \\
\hline
\end{tabular}

Rt, ordinary room; Fr, refrigerating room; Sr, snow room. $n=3$. a, b, c Different letters within a column indicate significant difference $(P<0.05)$.

よそ $12 \%$ であり，冷蔵室内の小麦粉試料の水分はこれ に近い値を示した。

一方，常温貯蔵に扔いては測定終了時の湿度は $62 \%$ と 雪室の $57 \%$ に近い値であり，この值が試料の水分量に反 映されたものと考えられる，ただし，常温においては前 述のように覆い内部の湿度が気温に相関して変動したこ とから, 試料の水分量もそれに応じて変動したものと考 えられる。一方，雪室貯蔵に扔いては，覆い内部の湿度 と温度に大きな変動はみられなかったことから, 水分量 に関しても一定の状態で試料を保存できるものと考えら れる。.これらのことから, 試料の水分は適切な覆いがな されている状態では，初期水分量が適切である限り雪室 貯蔵に扔いても過剩湿度になることはなく，一定の状態 を保つことができる可能性が示された．

\section{4 遊離グルコース量}

貯蔵による試料の品質変化をみるために, 試料中の 遊離グルコース生成量を測定した結果を Table 2 に示 す. 強力粉では，常温貯蔵に比べ冷蔵室貯蔵と雪室貯 蔵で遊離グルコース量が有意に低下して抢り，低温下 に貯蔵することによりデンプン分解が抑制されたこと が示唆された．全粒粉は強力粉の 2 倍近くの遊離グル コースを含んで打り, 強力粉よりも差が小さかったも のの, 常温貯蔵に比べ雪室貯蔵で遊離グルコース量が 有意に低下していた。

\section{3 遊離脂肪酸量および過酸化脂質量}

遊離脂肪酸と過酸化脂質の生成は小麦のグルテン形 成と製パン・製䁉性に大きく影響する。適度量の遊離 脂肪酸の生成は風味の向上に寄与するが，過剩に熟成 して「枯れた」状態になった小麦粉ではグルテン形成

Table 2 Free glucose content $(\mathrm{mg} / 100 \mathrm{~g}$, wet basis) of wheat flours stored under different conditions.

\begin{tabular}{ccc}
\hline & Strong flour & Whole grain flour \\
\hline Rt & $40.1 \pm 3.9^{\mathrm{a}}$ & $73.8 \pm 2.9^{\mathrm{a}}$ \\
$\mathrm{Fr}$ & $26.6 \pm 1.8^{\mathrm{b}}$ & $63.6 \pm 4.2^{\mathrm{ab}}$ \\
$\mathrm{Sr}$ & $25.2 \pm 1.9^{\mathrm{b}}$ & $63.3 \pm 7.0^{\mathrm{b}}$ \\
\hline
\end{tabular}

Rt, ordinary room; Fr, refrigerating room; Sr, snow room. $n=4$.

a, b Different letters within a column indicate significant difference $(P<0.05)$.
能の低下により，製パン·製糆性が低下することとなる. また，脂質過酸化物はグルテンの形成を阻害するとと もに，分解されて生じたアルデヒド類やケトン類など が不快臭や雑味の原因となり，さらに重合した過酸化 物が粘度を増加させることにより食味や風味を低下さ せる，小麦粉中の遊離脂肪酸量は，全粒粉，強力粉と もに，常温貯蔵に比べて冷蔵室貯蔵と雪室貯蔵で有意 に低下した（Fig. 2)。一方，TBA 法で測定した小麦粉

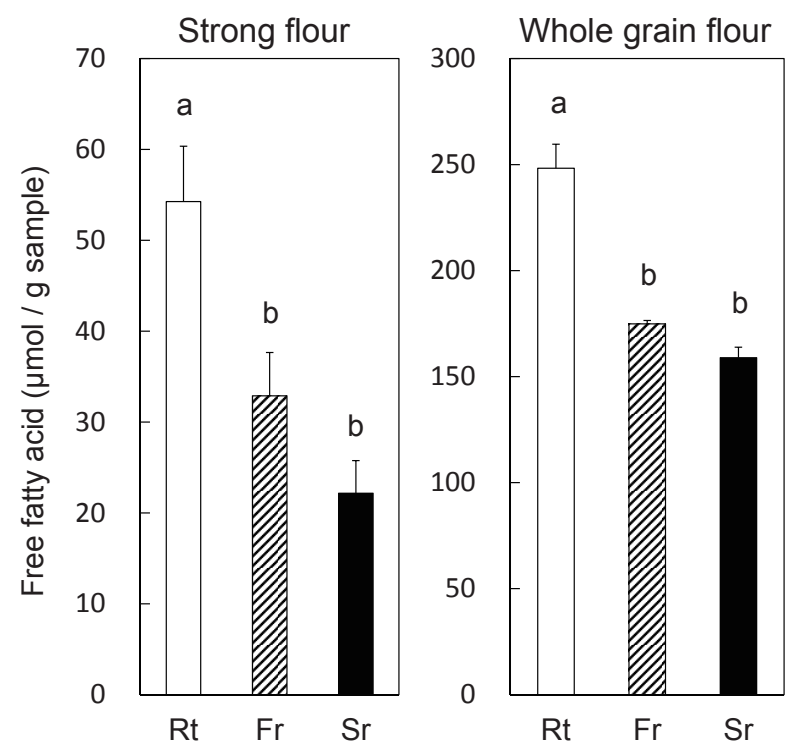

Fig 2 Generation of free fatty acid in the wheat flours stored under different conditions.

Rt, ordinary room; Fr, refrigerating room; Sr, snow room. $n=4 .{ }^{\mathrm{a}, \mathrm{b}}$ Different letters above bars indicate significant differences $(P<0.05)$.
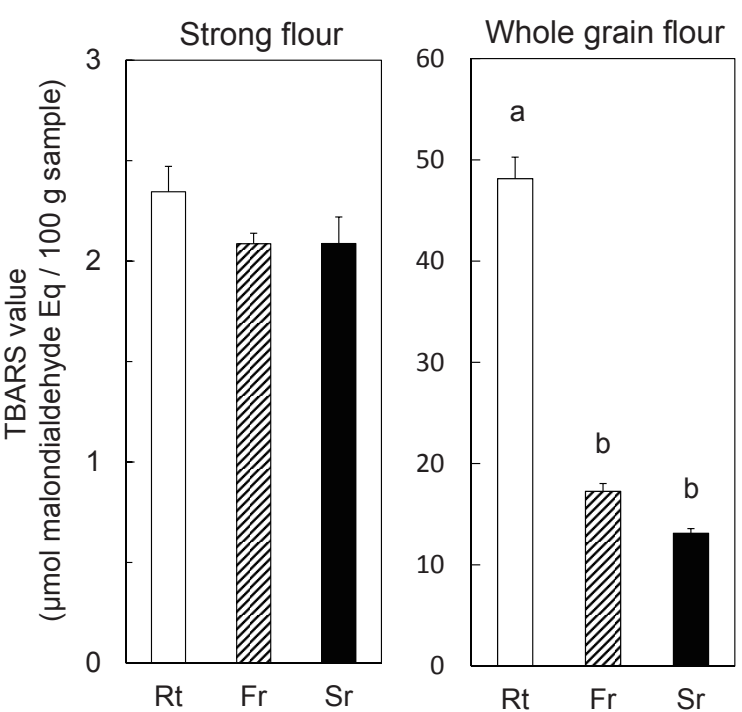

Fig. 3 Lipid peroxidation in the wheat flours stored under different conditions.

Rt, ordinary room; Fr, refrigerating room; Sr, snow room. $n=4$. ${ }^{\mathrm{a}, \mathrm{b}}$ Different letters above bars indicate significant differences $(P<0.05)$. 
Table 3 Gluten formation ability and bread-making performance of the wheat flours stored under different conditions.

\begin{tabular}{cccccc}
\hline & $\begin{array}{c}\text { Wet gluten } \\
\text { content }(\%)\end{array}$ & $\begin{array}{c}\text { Dry gluten } \\
\text { content (\%) }\end{array}$ & Loaf height $(\mathrm{cm})$ & Loaf weight $(\mathrm{g})$ & $\begin{array}{c}\text { Loaf volume } \\
\left(\mathrm{cm}^{3}\right)\end{array}$ \\
\hline $\mathrm{Rt}$ & $35.3 \pm 1.2^{\mathrm{a}}$ & $12.3 \pm 0.3^{\mathrm{a}}$ & $15.4 \pm 0.5^{\mathrm{a}}$ & $412 \pm 11$ & $1720 \pm 64^{\mathrm{a}}$ \\
$\mathrm{Fr}$ & $42.7 \pm 2.3^{\mathrm{b}}$ & $14.5 \pm 0.7^{\mathrm{b}}$ & $16.4 \pm 0.5^{\mathrm{b}}$ & $408 \pm 8$ & $1924 \pm 30^{\mathrm{b}}$ \\
$\mathrm{Sr}$ & $43.9 \pm 2.1^{\mathrm{b}}$ & $14.9 \pm 0.8^{\mathrm{b}}$ & $17.0 \pm 0.6^{\mathrm{b}}$ & $405 \pm 8$ & $1975 \pm 23^{\mathrm{b}}$ \\
\hline
\end{tabular}

Rt, ordinary room; Fr, refrigerating room; Sr, snow room. Gluten content, $n=4$; Loaf height and weight, $n=5$.

${ }^{\mathrm{a}, \mathrm{b}}$ Different letters within a column indicate significant difference $(P<0.05)$.

中の過酸化脂質量は, 脂質含量の多い全粒粉に打いて 有意差が認められ，常温貯蔵に比べて冷蔵室貯蔵と雪 室貯蔵で大きく過酸化脂質量が低下した（Fig. 3).

脂質の酸化は高温の状態で増加することから，冷蔵 室貯蔵と雪室貯蔵では，低温下で保存されることによ り脂肪の分解と脂質過酸化が抑制され，品質が保持さ れたものと考えられる. 冷蔵室保存と雪室保存との比 較では, 有意差は認められなかったものの, 雪室貯蔵 でやや遊離脂肪酸と過酸化脂質の生成が抑制される傾 向がみられた。

\section{5 グルテン形成能と製パン製への影響}

それぞれの条件で保存した小麦粉の製パン性につい て, 強力粉と全粒粉を $1: 1$ で混和した全粒粉パンを作 成して評価した。湿䞨量・乾焚量でみたグルテン形成 能については，ともに常温貯蔵に比べて冷蔵室貯蔵と 雪室貯蔵とで有意に増加していた（Table 3)。乾麥内部 の組織状態の比較では, 常温貯蔵は大きな空胞があり, もろく，不均一であったのに対し，冷蔵室貯蔵では空 胞は部分的であり, 雪室貯蔵では空胞も少なく均質で あった (Fig. 4 上)。ホームベーカリーで作成した食パ ンの代表例を Fig. 4 下に示す. パンの平均の重量には 有意差はみられなかったが, 高さは常温町蔵に比べて 冷蔵室貯蔵，雪室貯蔵ともに有意に増加して打り，体 積の評価でも同様に常温貯蔵に比べて冷蔵室貯蔵と雪

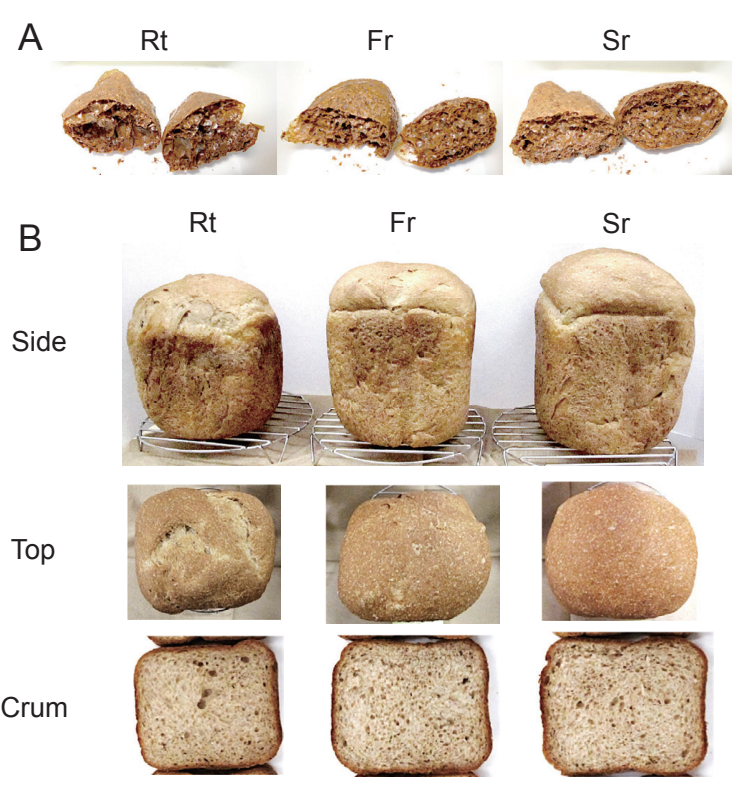

Fig. 4 Appearances of dry gluten and bread loaf made from wheat flours stored under different conditions.

A. The structure of the dry gluten. B. Appearance of the baked bread. Rt, ordinary room; Fr, refrigerating room; Sr, snow room.

室貯蔵で増加していた（Table 3)。冷蔵室貯蔵と雪室貯 蔵との間に有意差はみられなかったが，パンの重量と 体積から求めた気孔率（\%）の平均値は常温 417, 冷蔵 472, 雪室 488 であり, 雪室貯蔵, 冷蔵室貯蔵, 常温貯 蔵の順にふっくらと焼きあがる傾向がみられた。

Table 4 Crumb texture of sliced bread made from the wheat flours stored under different conditions.

\begin{tabular}{|c|c|c|c|c|c|c|c|}
\hline & & $\begin{array}{c}\text { Hardness } \\
\left(\mathrm{kN} / \mathrm{m}^{2}\right)\end{array}$ & $\begin{array}{c}\text { Adhesiveness } \\
\left(\mathrm{kN} / \mathrm{m}^{2}\right)\end{array}$ & $\begin{array}{c}\text { Cohesiveness } \\
\text { (Ratio) }\end{array}$ & $\begin{array}{l}\text { Springiness } \\
\text { (Ratio) }\end{array}$ & $\begin{array}{c}\text { Gumminess * } \\
\left(\mathrm{kN} / \mathrm{m}^{2}\right)\end{array}$ & $\begin{array}{c}\text { Chewiness ** } \\
\left(\mathrm{kN} / \mathrm{m}^{2}\right)\end{array}$ \\
\hline \multirow[t]{3}{*}{ Top } & $\mathrm{Rt}$ & $4.82 \pm 0.82^{\mathrm{a}}$ & $0.00 \pm 0.00$ & $0.77 \pm 0.04$ & $0.92 \pm 0.02$ & $3.72 \pm 0.73^{\mathrm{a}}$ & $3.42 \pm 0.74^{\mathrm{a}}$ \\
\hline & $\mathrm{Fr}$ & $3.36 \pm 1.01^{\mathrm{ab}}$ & $0.00 \pm 0.00$ & $0.84 \pm 0.12$ & $0.92 \pm 0.05$ & $2.77 \pm 0.61^{\mathrm{ab}}$ & $2.55 \pm 0.53^{\mathrm{ab}}$ \\
\hline & $\mathrm{Sr}$ & $2.94 \pm 0.36^{\mathrm{b}}$ & $0.00 \pm 0.00$ & $0.77 \pm 0.06$ & $0.92 \pm 0.01$ & $2.26 \pm 0.12^{b}$ & $2.01 \pm 0.09^{b}$ \\
\hline \multirow[t]{3}{*}{ Middle } & $\mathrm{Rt}$ & $6.43 \pm 2.02^{\mathrm{a}}$ & $0.00 \pm 0.00$ & $0.80 \pm 0.01$ & $0.95 \pm 0.01^{\mathrm{a}}$ & $5.14 \pm 1.61^{a}$ & $4.86 \pm 1.52^{\mathrm{a}}$ \\
\hline & $\mathrm{Fr}$ & $3.89 \pm 0.49^{b}$ & $0.00 \pm 0.00$ & $0.80 \pm 0.02$ & $0.90 \pm 0.02^{b}$ & $3.13 \pm 0.48^{\mathrm{ab}}$ & $2.83 \pm 0.44^{b}$ \\
\hline & $\mathrm{Sr}$ & $3.59 \pm 0.07^{\mathrm{b}}$ & $0.00 \pm 0.00$ & $0.81 \pm 0.01$ & $0.93 \pm 0.01^{\mathrm{ab}}$ & $2.91 \pm 0.09^{b}$ & $2.69 \pm 0.10^{b}$ \\
\hline \multirow[t]{3}{*}{ Bottom } & $\mathrm{Rt}$ & $9.81 \pm 2.01^{\mathrm{a}}$ & $0.00 \pm 0.00$ & $0.72 \pm 0.04$ & $0.92 \pm 0.01$ & $6.98 \pm 1.22$ & $6.43 \pm 1.14$ \\
\hline & $\mathrm{Fr}$ & $7.80 \pm 2.44^{\text {ab }}$ & $0.00 \pm 0.00$ & $0.72 \pm 0.06$ & $0.92 \pm 0.02$ & $5.73 \pm 2.23$ & $5.29 \pm 2.09$ \\
\hline & $\mathrm{Sr}$ & $5.10 \pm 1.06^{\mathrm{b}}$ & $0.00 \pm 0.00$ & $0.78 \pm 0.02$ & $0.92 \pm 0.02$ & $3.95 \pm 0.77$ & $3.64 \pm 0.64$ \\
\hline
\end{tabular}

Rt, ordinary room; Fr, refrigerating room; Sr, snow room.

${ }^{\mathrm{a}, \mathrm{b}}$ Different letters within a column indicate significant difference $(P<0.05) \quad$. $n=4$.

${ }^{*}$ hardness $\times$ cohesiveness ${ }^{* *}$ hardness $\times$ cohesiveness $\times$ springiness 
テクスチャ試験機を用いたそれぞれの食パンのテク スチャの評価では，パンの上部，中央部，下部に分け て測定したが，パンの上部に打いては，常温貯蔵に比 ベて雪室貯蔵のみ硬さとガム性，咀嚼性が有意に低下 した (Table 4). 中央部においては，常温貯蔵に比べて 冷蔵室貯蔵と雪室貯蔵で有意に硬さと咀嚼性が低下し た。下部においては，常温貯蔵に比べて雪室貯蔵のみ 硬さが有意に低下した。これらの結果から，雪室貯蔵 した小麦粉で作成したパンは全体的に均質に大きく焼 きあがっており，やわらかく咀嚼に必要なエネルギー も低いことが示された。

\section{6 官能検査による評価}

それぞれの食パンについて，女子学生 48 人（20〜 22 歳の健康的な女性）を対象とし，順位法と評価法により 官能検査を行った. 順位の合計点は, 常温貯蔵で 104 点, 冷蔵貯蔵で 97 点, 雪室貯蔵で 81 点であり, 常温貯蔵と 雪室貯蔵との間のみ有意差が認められた $(P<0.05)$ 。評 価法では,「色」,「香り」,「もっちり感」,「しっとり感」, 「味」，「総合評価」の 6 つの項目について 5 段階評価を 行ったが，味と総合評価において，常温貯蔵に比べ雪 室貯蔵で有意に好まれることが示された（Fig. 5)。順 位法, 評価法ともに, 雪室貯蔵の評価がもつとも高く, また常温貯蔵と冷蔵室貯蔵との間で有意差は認められ なかったことから，食パンの食味においては冷蔵室貯 蔵よりも雪室貯蔵の方が有効であることが示唆された。

\section{4. 結論}

本研究により，常温貯蔵に比べ冷蔵室貯蔵と雪室貯 蔵により小麦粉の品質劣化が抑えられるとともに，グ ルテン形成能と製パン性が向上し，よりふっくらとし たパンを作成できることが示された。強力粉と全粒粉 で作成した食パンの食味については，常温貯蔵の小麦 粉で作成した食パンに比べて雪室貯蔵のパンが有意に 好まれることが明らかにされ，特に雪室貯蔵の有効性 が示された。これらの結果から，低温・低湿度で保存 することが推奨されていた小麦の貯蔵においても，雪 室貯蔵が有効である可能性が示された。本研究では 3 ケ 月という短期間の貯蔵であったため, 脂質含量の多い 全粒粉以外の試料での有効性は限定的であった。さら に長期間の保存により，雪室貯蔵の有効性がより明確 になるものと期待される.

雪を利用した貯蔵方法は電力を必要とせず二酸化炭 素を排出しない貯蔵方法であることから，近年では， 雪や水を利用する氷雪冷熱が環境に優しい冷熱エネル ギーとして見直されており，雪室貯蔵を利用した高付 加価值食品の製造が広がりつつある。今後，小麦やコ メのような穀物に対しても雪室貯蔵が活用されること

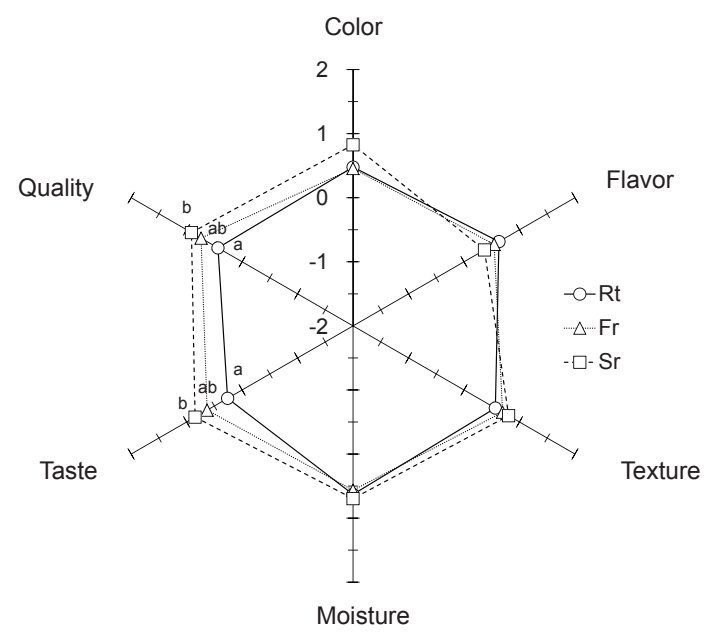

Fig. 5 Sensory evaluation of the baked breads.

Each attribute was expressed on a five-point scale from -2 (bad) to +2 (good) . Rt, ordinary room; Fr, refrigerating room; Sr, snow room. Different letters within a scale indicate significant differences $(P<0.05)$.

により，氷雪エネルギー源として雪資源が有効に利用 されることが望まれる。

謝辞

本研究は平成 25 年度飯島藤十郎記念食品科学振興財 団学術研究助成金の補助を受けて行われた。

\section{引用 文 献}

1) K. Ishihara, H. Suzuki, S. Tsuchida, K. Umano, Y. Hagi, Y. Yokoyama; "Change in volatile compounds in carrot stored under snowy ground” (in Japanese) . Hort. Res. (Japan) , 4, 353-357 (2005) .

2) K. Muramatsu; "Snow storage of vegetables" (in Japanese). Bull. Hokuriku Natl. Agric. Exp. Stn., 29, 75-94 (1987) .

3) H. Sone, M. Oshimi, M. Ito, M. Ishiguro, T. Tsuji, K. Kobayashi, S. Watanabe, S. Kamiyama; "Effect of snow room storage on changes in aromatic compounds of roasted coffee beans" (in Japanese) . Trace Nutrients Res., 31, 12-16 (2014) .

4) S. Kamiyama, M. Itoh, M. Oshimi, M. Takiguchi, S. Kushihara, M. Ishiguro, K. Kobayashi, S. Shimojo, S. Watanabe, H. Sone; "The efficacy of snow room (yukimuro) storage for the preservation of buckwheat grain” (in Japanese) . Bull. Soc. Hum. Life Stud., 6, 83-92 (2015) .

5) K. Otsubo, H. Yanase, T. Ishima; "Colorimetric determination of fat acidity of rice” (in Japanese) . Rep. Natl. Food Res. Inst., 51, 59-65 (1987).

6) C. G. Sidwell, H. Salwin, M. Benca, J. H. Mitchell; "The use of thiobarbituric acid as a measure of fat oxidation" . J. Am. Oil Chem. Soc., 31, 603-606 (1954) . 